Abdul Mun'im

Universitas Negeri Makassar

Sitti Rahma Yunus

Universitas Negeri Makassar

Awaluddin Aksa

Universitas Negeri Makassar

\section{PENGARUH PENDEKATAN SAINS TEKNOLOGI MASYARAKAT (STM) TERHADAP MOTIVASI DAN HASIL BELAJAR PESERTA DIDIK KELAS VIII SMP NEGERI 1 PANGKAJENE (STUDI PADA MATERI POKOK PESAWAT SEDERHANA)}

Abstrak: Penelitian ini adalah eksperimen semu yang tujuan penelitian ini adalah untuk (1) Untuk mengetahui Pengaruh Pendekatan Sains Teknologi dan Masyarakat (STM) terhadap motivasi belajar peserta didik kelas VII SMP Negeri 1 Pangkajene pada materi pesawat sederhana. (2) Untuk mengetahui Pengaruh Pendekatan Sains Teknologi dan Masyarakat (STM) terhadap hasil belajar peserta didik kelas VII SMP Negeri 1 Pangkajene pada materi pesawat sederhana. Tahun ajaran 2016/2017. Pengambilan sampel menggunakan teknik Porposive Sampling. Sampel penelitian yang digunakan 38 orang pada kelas eksperimen dan 38 orang pada kelas kontrol. Penelitian ini menggunakan instrument Angket untuk mengukur motivasi belajar dan instrument soal pilihan ganda untuk mengukur hasil belajar peserta didik. Hasil penelitian mengungkapkan bahwa rata-rata nilai motivasi dan hasil belajar peserta didik yang diajarkan dengan pendekatan Sains Teknologi Masyarakat dibandingkan data nilai motivasi dan hasil belajar kelas kontrol denngan menggunakan pembelajaran konvensional. Hasil analisis inferensial dengan menggunakan uji-t motivasi belajar diperoleh nilai $t_{\text {hitung }}$ sebesar 2,2 dan nilai $t_{\text {tabel }}$ adalah 1,66. Dari hasil perhitungan Uji-t hasil belajar diperoleh $t_{\text {hitung }}>t$ tabelyaitu 2,35> 1,66 sehingga $H_{0}$ ditolakdan $H_{1}$ diterima, maka dapat disimpulkan bahwa adapengaruh positif pendekatan STM terhadap hasil belajar peserta didik kelas VIII SMP Negeri 1 Pangkajene. Oleh karena itu, dapat disimpulkan bahwa terdapat pengaruh pendekatan STM terhadap motivasi dan hasil belajar hasil belajar IPA peserta didik kelas VIII SMP Negeri 1 Pangkajene pada materi pesawat sederhana.

Kata Kunci: Pendekatan, Pendekatan Sains Teknologi Masyarakat, Motivasi, Hasil Belajar.

Abstract: The reaserch is quasi eksperiment that purpose of this research is to (1) To know the Influence of Approach of Science of Technology and Society (STM) to motivation learn class VII students SMP NEG 1 Pangkajene on simple plane material. (2) To know the Influence of Science Approach of Technology and Society (STM) to learning result of student of class VII of SMP NEG 1 Pangkajene on simple plane material. The academic year 2016/2017. Sampling using purposive sampling. The study sample used 38 people in the experimental class and 38 people in the control class. This research using the Questionnaire instrument to measure learning motivation and multiple-choice instruments to measure 
learners' learning outcomes. The results revealed that the average value of motivation and learning outcomes of students taught with the approach of Community Technology Science compared the data value of motivation and learning outcomes control class using conventional learning. The results of inferential analysis using t-test learning motivation obtained $t$ value of 2.2 and $t$ table is 1.66. From the calculation of T-test

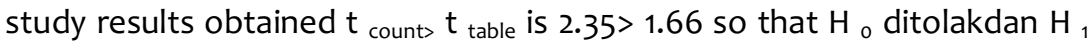
received, it can be concluded that the positive adapengaruh STM approach to the study of students of class VIII SMP Negeri 1 Pangkajene. Therefore, it can be concluded that there is influence STM approach to motivation and learning outcomes of science learning outcomes of students class VIII SMP Negeri 1 Pangkajene on simple plane materials.

Keywords: Approach, Science,Technology\&Society, Motivation, Learning Outcomes

\section{PENDAHULUAN}

Tujuan pendidikan yang diharapkan Pemerintah dikutip dalam Undang Undang No. 20 Tahun 2003 tentang sistem pendidikan nasional pasal 1 (2009:17) tentang pendidikan yaitu usaha sadar manusia dan terencana untuk mewujudkan suasana belajar dan proses pembelajaran agar peserta didik secara aktif mengembangkan potensi dirinya untuk memiliki kekuatan spiritual keagamaan, pengalaman diri, kepribadian, kecerdasan, ahklak mulia, serta keterampilan yang diperlukan dirinya, masyarakat, bangsa dan Negara. Dalam kutipan undang-undang di atas tujuan pendidikan sangat erat kaitannya dengan proses pembelajaran.

Dalam proses pembelajaran tentunya diperlukan adanya suasana yang kondusif. Agar dapat menciptakan suasana belajar dan proses pembelajaran sebagaimana tercantum dalam UndangUndang No. 20 tahun 2003, Maka penting bagi pendidik untuk memberikan suasana pembelajaran yang menarik. Dengan pembelajaranyang menarik yang diterapkan pendidik maka bukan tidak mungkin tujuan pembelajaran dapat tercapai.

Dewasa ini ilmu pengetahuan dan teknologi (IPTEK) berkembang dengan pesat. Hal tersebut dapat dilihat melalui penggunaan dan pemanfaatan produk-produk hasil teknologi dalam berbagai aspek kehidupan untuk memenuhi kebutuhan hidup sehari-hari. Namun, produk hasil teknologi tersebut dapat menimbulkan dampak yang merugikan bagi manusia dan lingkungannya secara utuh. Untuk menanggulangi dampak negative yang ditimbulkan, dibutuhkan sumber daya manusia yang berkualitas yang mampu menguasai IPTEK sehingga dapat mengimbangi perkembangan kemajuan sains dan teknologi (Agustini et al, 2013).

Fokus dalam proses pendidikan adalah pada peserta didik yang melibatkan diri dalam kegiatan belajar dan tidak mengutamakan pada kegiatan mengajar yang secara penuh didominasi oleh pendidik atau guru. Proses pendidikan di sini dijabarkan dalam proses pembelajaran yaitu kegiatan peserta didik untuk belajar sedangkan pendidik atau guru berperan untuk membantu peserta didik dalam melakukan kegiatan belajar (Sudjana 2005).

Keberhasilan program pendidikan melalui pembelajaran di sekolah sebagai lembaga pendidikan formal sangat dipengaruhi oleh beberapa faktor yaitu: siswa, kurikulum, tenaga kependidikan, biaya, sarana dan prasarana serta faktor lingkungan. Apabila faktor-faktor tersebut dapat terpenuhi sudah tentu akan memperlancar proses belajar-mengajar, yang akan menunjang pencapaian hasil belajar yang maksimal yang pada akhirnya akan meningkatkan mutu pendidikan. Untuk menciptakan suasana pembelajaran IPA yang menarik, menantang, dan bermakna bagi 
siswa, guru harus pandai-pandai merancang strategi pembelajaran, memanfaatkan multi media, multi metode, dan multi aspek (logika, praktika, estetika ) (Renold et al, 2013).

Berdasarkan observasi yang dilakukan di SMP Neg 1 Pangkajene kebanyakan peserta didik di SMP NEG 1 Pangkajene tidak memiliki motivasi serta perhatian terhadap mata pelajaran IPA khususnya pada materi fisika seperti pesawat sederhana, terlebih lagi banyak peserta didik yang kurang suka dengan pelajaran yang membutuhkan perhitungan seperti fisika. Menurut beberapa Pendidik di SMP NEG 1 Pangkajene bahwa hanya peserta didik yang termasuk dalam kategori peringkat sepuluh besar yang lebih cenderung termotivasi belajar, dan selebihnya ada yang malas, dan cenderung tidak memperhatikan pembelajaran. Oleh karena itu motivasi yang kurang dalam pembelajaran berdampak pada hasil belajar peserta didik menjadi rendah hal tersebut bisa dilihat dari rata-rata hasil ulangan harian peserta didik pada pelajaran IPA seperti pada materi gaya yang masih di bawah nilai KKM sekolah yakni 68.Dalam proses pembelajaran hanya terjadi komunikasi satu arah antara guru dengan siswa, guru lebih banyak menggunakan metode ceramah sehingga siswa merasa bosan dan mengantuk.

Seperti diketahui, bahwa pembelajaran IPA lebih banyak berisi tentang permasalahan alam yaitu selalu berkaitan dengan lingkungan sekitar yang ada dalam kehidupan anak. Walaupun alam dapat dilihat secara langsung namun masih banyak siswa yang mengalami kesulitan memahami pembelajaran IPA, padahal IPA sangat penting dan berguna jika dipelajari dengan sungguhsungguh. Salah satu kesulitan yang dialami siswa adalah siswa tidak dapat melihat secara langsung objek yang dijadikan bahan pelajaran, padahal bahan ajar tersebut berada disekitar mereka. Anak akan lebih senang jika dia dapat menemukan sendiri atau mengalami secara langsung sehingga mereka bisa dengan mudah mengingat apa yang telah dipelajarinya (Lestari et al, 2012).

Upaya yang dapat dilakukan untuk meningkatkan motivasi dan hasil belajar IPA kelas VIII SMP NEG 1 Pangkajene adalah dengan menerapkan salah satu pendekatan yang diharapkan sesuai dengan pembelajaran IPA saat ini yaitu dengan pendekatan Sains Teknologi Masyarakat (STM). Pendekatan STM menitikberatkan pada penyelesaian masalah dan proses berpikir yang melibatkan transfer jarak jauh. Konsep-konsep yang diperoleh pada proses pembelajaran dapat diterapkan pada |kehidupan sehari-hari.

"Pembelajaran dengan menggunakan pendekatan STM memiliki ciri yang paling utama, yang dilakukan dengan memunculkan isu sosial di awal pembelajaran dan guru sebelumnya sudah memiliki isu yang sesuai dengan konsep yang akan diajarkan" (Poedjiadi, 2005).

STM dipandang sebagai proses pembelajaran yang senantiasa sesuai dengan konteks pengalaman manusia. Dalam pendekatan STM siswa diajak untuk meningkatakan kreativitas, sikap ilmiah, menggunakan konsep dan proses sains dalam kehidupan sehari-hari Penerapan pendekatan STM tentunya sangat baik digunakan dalam pembelajaran karena selalu mengaitkan materi dengan kehidupan serta lingkungan dunia nyata siswa. Akan tetapi, dalam proses pembelajaran tidak bisa setiap hari langsung mengajak siswa ke dalam pokok objek pembelajaran yang ada dalam lingkungan (Septiawan, 2014).

Berdasarkan sejarah perkembangan STM yang telah diuraikan maka harus diketahui apa sebenarnya STM menurut para ilmuwan. Galib (dalam Gita 2010) mengemukakan bahwa: Sains Teknologi Masyarakat (STM) merupakan terjemahan dari Science Teknology Society (STS) yaitu suatu usaha untuk menyajikan sains dan teknologi dalam konteks pengalaman dan kehidupan manusia sehari-hari, dengan fokus isu-isu atau masalah-masalah yang sedang dihadapi oleh masyarakat, baik bersifat lokal, regional, nasional maupun global yang memiliki komponen sains dan teknologi (Septiawan, 2014).

Rendahnya daya serap siswa dalam mata pelajaran IPA menunjukkan masih ada kesenjangan yang cukup besar antara tuntunan kurikulum dengan tingkatkemampuan siswa dalam hal belajar IPA. Guru dalam pembelajaran IPA di kelas lebih berorentasi pada kuantitas pembelajaran, yaitu menyelesaikan materi pelajaran yang termuat dalam kurikulum, model 
mengajar yang diterapkan masih bersifat langsung, guru memakai literatur yang relevan dan berlaku secara general, dan tidak melakukan pengkonkretan konsep sebelum proses belajar dimulai (Wahyudi, 2002).

Pendekatan STM merupakan pendekatan pembelajaran yang menekankan guru agar mampu menjelaskan kepada siswa masalah yang ada di masyarakat berkaitan dengan IPTEK melalui alat peraga dan media pembelajaran. Dengan demikian guru diharapkan dapat menyediakan alat peraga yang sesuai (Gunarto, 2011).

Dalam upaya mengatasi permasalahan yang telah diuraikan di atas, dalam membantu peserta didik di SMP agar peserta didik lebih termotivasi untuk ikut serta dalam pembelajaran maka penulis akan melakukan penelitian dengan judul "Pengaruh Pendekatan Sains Teknologi Masyarakat (STM) Terhadap Motivasi dan Hasil Belajar Peserta didik Kelas VIII SMP Negeri 1 Pangkajene pada Materi Pesawat sederhana"

\section{METODE}

Penelitian ini adalah Eksperimen Semu (Noneequivalent Control Grup Design) merupakan penelitian yang dilakukan dengan melibatkan dua kelompok belajar yang dimana kelompok satu diberikan perlakuan (kelompok eksperimen) dan kelompok kedua tidak diberikan perlakuan (kelas kontrol).

\section{Tabel 1. Desain Penelitian}

\begin{tabular}{cccc}
\hline Kelas & Pretest & Perlakuan & Posttest \\
\hline Eksperimen & $\mathrm{O}_{1}$ & $\mathrm{X}$ & $\mathrm{O}_{2}$ \\
Kontrol & $\mathrm{O}_{3}$ & - & $\mathrm{O}_{4}$ \\
\hline
\end{tabular}

Populasi dalam penelitian ini adalah semua peserta didik kelas VIII B - VIII K SMP Negeri Pangkajene tahun ajaran 2016/2017 yang terdiri dari 10 kelas.Teknik pengambilan sampel yang dilakukan adalah Porposive Sampling, pengambilan sampel yang dilakukan dengan pertimbangan yakni adanya kelas unggulan, dengan kemampuan peserta didik yang relative sama, yang dapat mewakili populasi. Kelas yang terpilih sebagai sampel adalah kelas VIII B selaku kelas kontrol dan kelas VIII E selaku kelas eksperimen.

Instrumen yang digunakan pada penelitian ini untuk mengukur :1) Motivasi belajar peserta didik diukur dengan menggunakan instrumen angket motivasi belajar dengan 30 item pernyataan yang dilengkapi empat alternative pilihan jawaban : 4). Sangat setuju 3). Setuju 2). Tidak setuju 1). Sangat tidak setuju. Indikator motivasi belajar dapat diklasifikasikan sebagai berikut: 1). Adanya hasrat dan keinginan berhasil ; 2). Adanya dorongan dan kebutuhan dalam belajar ; 3). Adanya harapan dan cita-cita masa depan; 4). Adanya penghargaan dalam belajar; 5) adanya kegiatan yang menarik dalam kelas; 6). Adanya lingkungan belajar yang kondusif, sehingga memungkinkan seseorang pesera didik dapat belajar dengan baik. 2) Hasil belajar peserta didik adalah instrumern tes hasil belajar yang digunakan untuk mengukur pemahaman peserta didik terhadap materi pokok pesawat sederhana. Tes hasil hasil belajar terdiri atas soal pilihan ganda sebanyak 25 butir soal yang terdiri dari empat pilihan dengan perolehan skor 1 untuk setiap jawabannya.

Teknik analisis data yang digunakan adalah analisis deskriptif dan inferensial. Analisi deskriptuf ini bertujuan untuk mendeskripsikan peningkatan pembelajaran dengan pendekatan STM pada pesrta didik untuk kelas eksperimen, yang terdiri dari nilai rata-rata (mean), standar deviasi, nilai tertinggi, dan nilai terendah. Serta Statistik inferensial merupakan analisis statistik yang digunakan untuk menganalisis data sampel dan hasilnya digunakan untuk populasi. Dan 
untuk menguji hipotesis dengan menggunakan uji-t. dimana data yang akan diuji dilakukan uji normalitas serta homogenitasnya.

\section{HASIL DAN PEMBAHASAN}

Motivasi belajar peserta didik kelas eksperimen dan kelas kontrol disajikan pada Tabel berikut.

Tabel 2. Statistik Deskriptif Motivasi Belajar IPA Peserta Didik Kelas Eksperimen dan Kontrol

\begin{tabular}{llcccc}
\hline \multirow{2}{*}{ No. } & \multirow{2}{*}{ Statistik } & \multicolumn{2}{c}{ Kelas Eskperimen } & \multicolumn{2}{c}{ Kelas Kontrol } \\
\cline { 3 - 6 } & & Pretest & Posttest & Pretest & Posttest \\
\hline 1. & Jumlah Sampel & 38 & 38 & 38 & 38 \\
2. & Skor Tertinggi & 89 & 113 & 94 & 111 \\
3. & Skor Terendah & 79 & 96 & 79 & 94 \\
4. & Skor Rata-rata & 85 & 104,65 & 85 & 102,02 \\
5. & Std. Deviasi & 2,64 & 5,20 & 2,99 & 4,64 \\
\hline
\end{tabular}

Tabel 3. Kategori Data Motivasi Belajar Peserta Didik Kelas Eksperimen dan Kelas Kontrol

\begin{tabular}{cccc}
\hline Skor & $\begin{array}{c}\text { Kelas } \\
\text { Eksperimen }\end{array}$ & Kelas kontrol & Kriteria \\
\hline $103-120$ & 23 & 19 & Sangat tinggi \\
$85-102$ & 15 & 19 & Tinggi \\
$67-84$ & 0 & 0 & Sedang \\
$49-66$ & 0 & 0 & Rendah \\
$30-48$ & 0 & 0 & Sangat rendah \\
\hline
\end{tabular}

Hasil belajar peserta didik kelas eksperimen dan kelas kontrol disajikan pada Tabel 4 berikut.

Tabel 4. Statistik Deskriptif Hasil Belajar Peserta Didik Kelas Eksperimen dan Kelas Kontrol

\begin{tabular}{lccccc}
\hline \multirow{2}{*}{ No } & \multirow{2}{*}{ Statistik } & \multicolumn{2}{c}{ Kelas Eksperimen } & \multicolumn{2}{c}{ Kelas Kontrol } \\
\cline { 2 - 6 } & Pretest & Posttest & Pretest & Posttest \\
\hline 1 & Jumlah sampel & 38 & 38 & 38 & 38 \\
2 & Nilai tertinggi & 72 & 100 & 72 & 96 \\
3 & Nilai Terendah & 8 & 60 & 8 & 56 \\
4 & Nilai rata-rata & 39,34 & 82,61 & 42,81 & 77,60 \\
5 & Std. Deviasi & 12,14 & 10,55 & 15,95 & 8,49 \\
\hline
\end{tabular}

Berdasarkan penelitian yang telah dilakukan pada materi pokok pesawat sederhana menunjukkan bahwa motivasi dan hasil belajar IPA peserta didik pada penerapan pendekatan Sains Teknologi Masyarakat (STM) lebih tinggi dibandingkan dengan nilai hasil belajar IPA pada penerapan pembelajaran konvensional, dalam hal ini menggunakan model yang sama namun tanpa menggunakan pendekatan STM. Terdapat perbedaan hasil belajar antara kelas eksperimen dan kelas kontrol karena kelas eksperimen menggunakan pendekatan STM, dimana dalam pembelajaran dengan pendekatan STM peserta didik dihadapkan pada masalah kontekstual yang kemudian dihubungkan dengan penggunaan serta pemanfaatan prinsip dari materi pesawat pada sebuah teknologi yang digunakan sehari-hari ataupun yang pernah dilihat dan dialami baik dari 
media ataupun secra langsunga, sehingga termotivasi untuk belajar yang kemudian dari motivasi belajar peserta didik yang tinggi kemudian akan berdampak pada hasil belajar peserta didik. Pada pembelajaran dengan pendekatan STM ini peserta didik setelah memahami konsep akan mengaitkannya dengan teknologi sehingga dapat dirasakan manfaatnya dan pendidik hanya membimbing peserta didik. Sedangkan pada kelas kontrol yang menggunakan pembelajaran langsung dengan pendekatan konvensional, dimana pendidik yang melakukan proses pembelajaran, menunjukkan dan menjelaskan suatu proses sehingga peserta didik bersifat pasif dan kurang termotivasi dalam proses pembelajaran.

Hasil analisis deskriptif motivasi belajar peserta didik yang diajar dengan pendekatan STM menunjukkan nilai rata-rata yang dicapai adalah 104,65 dan standar deviasi 5,20. Sedangkan pada kelas kontrol yang diajar dengan menggunakan model pembelajaran konvensional menunjukkan bahwa nilai rata-rata 102,02 dan standar deviasi 4,64. Hal ini berarti rata-rata motivasi belajar IPA kelas eksperimen masih lebih unggul bila dibandingkan dengan rata-rata hasil belajar IPA kelas kontrol. Sedangkan analisis deskriptif hasil belajar IPA peserta didik pada kelas eksperimen yang diajar dengan pendekatan STM menunjukkan nilai rata-rata yang dicapai adalah 82,61 dan standar deviasi 10,55. Sedangkan pada kelas kontrol yang diajar dengan menggunakan model pembelajaran konvensional menunjukkan bahwa nilai rata-rata 77,60 dan standar deviasi 8,49 . Hal ini berarti rata-rata hasil belajar IPA kelas eksperimen masih lebih unggul bila dibandingkan dengan rata-rata hasil belajar IPA kelas kontrol

Pengkategorian nilai motivasi peserta didik yang berdasarkan lampiran Kategori Nilai motivasi peserta didik didapatkan bahwa nilai motivasi peserta didik pada kelas eksperimen yang berada pada kategori sangat tinggi berjumlah 23 orang, pada kategori tinggi sebanyak 15 orang. Sedangkan pada kelas kontrol yang berada pada kategori sangat tinggi berjumlah 19 orang, pada kategori tinggi sebanyak 19 orang peserta didik.

Penelitian motivasi dan hasil belajar pada kelas eksperimen juga didukung dengan perhitungan persentase pencapaian indikator hasil belajar keseluruhan untuk materi pesawat sederhana pada kelas eksperimen lebih tinggi dibandingkan dengan kelas kontrol. Hal ini dapat dilihat pada rata-rata pencapaian indikator motivasi belajar kelas eksperimen dan kontrol sebesar $87,93 \%$ dan $85,02 \%$. Sedangkan pencapaian indikator hasil belajar peserta didik kelas eksperimen dan kelas kontrol adalah $82.06 \%$ dan $76,92 \%$. Adanya perbedaan peningkatan motivasi dan hasil belajar antara kelas eksperimen dan kelas kontrol disebabkan beberapa faktor. Salah satu diantaranya yaitu peserta didik di kelas eksperimen memiliki tambahan wawasan baru bahwa alat yang ada di sekeliling kita tidak hanya digunakan prinsipnya untuk hal yang biasa saja tetapi berawal dari proinsip tersebut juga diterapkan dalam teknologi, sedangkan pada kelas kontrol peserta didik cenderung pasif dan hanya menunggu penjelasan materi yang diberikan oleh pendidik.

Untuk memperkuat hasil dari analisis deskriptif diatas, maka dilakukan analisis statistik inferensial untuk membuktikan hipotesis yang diajukan. Sebelum melakukan uji-t, data harus berasal dari populasi yang terdistribusi normal dan homogen. Dari hasil pengujian yang dilakukan dengan menggunakan uji normalitas dan uji homogenitas diperoleh nilai motivasi dan hasil belajar IPA dari dua kelas tersebut terdistribusi normal dan homogen, sehingga pengujian hipotesis dapat dilakukan dengan menggunakan uji-t. Hasil analisis inferensial dengan menggunakan uji-t motivasi belajar diperoleh nilai $t_{\text {hitung }}$ sebesar 2,43 dan nilai $t_{\text {tabel }}$ adalah 1,66. Dari hasil perhitungan Uji-t hasil belajar diperoleh $t_{\text {hitung }}>t$ tabelyaitu 2,35>1,66 sehingga $H_{0}$ ditolakdan $H_{1}$ diterima, maka dapat disimpulkan bahwa terdapat pengaruh positif pendekatan STM terhadap hasil belajar peserta didik kelas VIII SMP Negeri 1 Pangkajene. Oleh karena itu, dapat disimpulkan bahwa terdapat pengaruh pendekatan STM terhadap motivasi dan hasil belajar hasil belajar IPA peserta didik kelas VIII SMP Negeri 1 Pangkajene pada materi pesawat sederhana.

Hasil penelitian yang diperoleh didukung hasil penelitian yang terkait tentang STM terhadap motivasi adalah yang dilakukan oleh Sari (2013) yang menyatakan adanya peningkatan motivasi 
belajar peserta didik dengan penerapan STM. Adapun penelitian mengenai pendekatan STM terhadap hasil belajar peserta didik oleh Renold et all (2013), yang menyatakan bahwa pendekatan Sains Teknologi dan Masyarakat (STM) efektif untuk meningkatkan Hasil belajar peserta didik. Lebih lanjut penelitian Yogi Adi Kuncoro (2012) menunjukkan adanya peningkatan hasil belajar dan motivasi peserta didik dengan penerapan pendekatan STM. Serta penelitian Hasjunianti (2014) yang menyatakan penerapan pendekatan STM dapat meningkatkan pemahaman peserta didik.

\section{KESIMPULAN}

Berdasarkan hasil penelitian yang dilaksanakan mengenai pembelajaran dengan Pendekatan Sains Teknologi Masyarakat (STM) terhadap motivasi dan hasil belajar peserta didik di SMPN 1 Pangkajene diperoleh beberapa kesimpulan sebagai berikut:

1. Terdapat pengaruh positif pendekatan sains Teknologi Masyarakat terhadap Motivasi belajar peserta didik kelas VIII SMPN 1 Pangkajene materi pokok pesawat sederhana .

2. Terdapat pengaruh positif pendekatan sains Teknologi Masyarakat terhadap hasil belajar peserta didik kelas VIII SMPN 1 Pangkajene materi pokok pesawat sederhana

\section{DAFTAR PUSTAKA}

Agustini, D., Subagia, IW. \& Suardana I N. 2013. Pengaruh Model Pembelajaran Sains Teknologi Masyarakat (STM) Terhadap Penguasaan materi dan Keterampilan Pemecahan Masalah siswa Pada Mata Pelajaran IPA di MTs Negeri Patas. E-Journal Program Pascasarjana Universitas Pendidikan Ganesha. Vol. 3.

Gunarto, W. \& Hidayah, N. 2014. Upaya Meningkatkan minat Belajar dan Prestasi Belajar Siswa pada Materi Pembelajaran Alat-alat Optik Melalui Pendekatan sains Teknologi masyarakat di kelas VIII SMPN 3 Belitang Madang Raya. Jurnal Inovasi dan Pembelajaran Fisika. Vol. 1 no.1 ISSN. 23555-7109.

Lestari, Syahruddin \& Jampel. Pengaruh pendekatan Sains teknologi masyarakat (STM) terhadap hasil belajar siswa kelas IV SD di Gugus III Kecamatan Tegalallang. Jurnal Pendidikan ganesha.

Poedjiadi, A. 2005. Sains Teknologi Masyarakat. Model Pembelajaran Bermuatan Nilai. Remaja Rosdakarya: Bandung.

Renold., J., \& Rede, A. 2013. Meningkatkan hasil belajar siswa melalui Pendekatan Sains teknologi masyarakat (STM) pada pembelajaran IPA pokok bahasan daur air siswa. Jurnal kreatif Tadulako Online. Vol 1 no 2 : ISSN 2354 64X.

Septiawan, Krista I Gd. Arini, Ni Wy. \& Wawan, Sudata I Gd. 2014. Penerapan Pendekatan Sains Teknologi masyarakat (STM) berbantuan media Audio Visual untuk Meningkatkan Hasil Belajar IPA pada siswa kelas V semester ganji di SD Negeri 2 Sudaji, Kecamatan Sawan, Kabupaten Buleleng tahun pelajaran 2013/2014. Jurnal Mimbar PGSD undiksha. Vol 2 No.1 Tahun 2014.

Sudjana, N. 2015. Penilaian Hasil Proses belajar Mengajar. Bandung: PT Remaja Roskakarya.

Sugiyono. 2014. Metode Penelitian Kuantitaf Kualitatif Dan R\&D. Alfabeta: Bandung

Wahyudi, 2002. Tingkat Pemahaman Siswa terhadap Materi Pembelajaran IPA. Jurnal pendidikan dan Kebudayaan. Vol 3(6). Hal 389. 


\section{Abdul Mun'im}

Dosen Prodi Pendidikan IPA Universitas Negeri Makassar, aktif meneliti di bidang pembelajaran IPA, dapat dihubungi melalui pos-el: abdulmunim@unm.ac.id

\section{Sitti Rahma Yunus}

Dosen Prodi Pendidikan IPA Universitas Negeri Makassar, aktif meneliti di bidang pembelajaran IPA dan fisika, dapat dihubungi melalui pos-el: sitti.rahma.yunus@unm.ac.id

Awaluddin Aksa

Alumni Prodi Pendidikan IPA Universitas Negeri Makassar 